\title{
Impact of three years of large scale Indoor Residual Spraying (IRS) and Insecticide Treated Nets (ITNs) interventions on insecticide resistance in Anopheles gambiae s.l. in Benin
}

Gil Germain Padonou ${ }^{1,2^{*}}$, Michel Sezonlin², Razaki Ossé ${ }^{1,2}$, Nazaire Aizoun $^{1,2}$, Frédéric Oké-Agbo ${ }^{1}$, Olivier Oussou ${ }^{1}$, Ghélus Gbédjissi ${ }^{2}$ and Martin Akogbéto ${ }^{1,2}$

\begin{abstract}
Background: In Benin, Indoor Residual Spraying (IRS) and long-lasting insecticidal nets (LLINs) are the cornerstones of malaria prevention. In the context of high resistance of Anopheles gambiae to pyrethroids, The National Malaria Control Program (NMCP) has undertaken a full coverage of IRS in a no-flood zone in the Oueme region, coupled with the distribution of LLINs in a flood zone. We assessed the impact of this campaign on phenotypic resistance, $k d r$ (knock-down resistance) and ace- $1^{R}$ (insensitive acetylcholinesterase) mutations.

Methods: Insecticides used for malaria vector control interventions were bendiocarb WP $\left(0.4 \mathrm{~g} / \mathrm{m}^{2}\right)$ and deltamethrin $\left(55 \mathrm{mg} / \mathrm{m}^{2}\right)$, respectively for IRS and LLINs. Susceptibility status of An. gambiae was assessed using World Health Organization bioassay tests to DDT, permethrin, deltamethrin and bendiocarb in the Oueme region before intervention (2007) and after interventions in 2008 and 2010. An. gambiae specimens were screened for identification of species, molecular M and S forms and for the detection of the West African $k d r$ (L1014F) as well as ace- $1^{R}$ mutations using PCR techniques.

Results: The univariate logistic regression performed showed that $k d r$ frequency has increased significantly during the three years in the intervention area and in the control area. Several factors (LLINS, IRS, mosquito coils, aerosols, use of pesticides for crop protection) could explain the selection of individual resistant An. gambiae. The Kdr resistance gene could not be the only mechanism of resistance observed in the Oueme region. The high susceptibility to bendiocarb is in agreement with a previous study conducted in Benin. However, the occurrence of ace- $1^{R}$ heterozygous individuals even on sites far from IRS areas, suggests other factors may contribute to the selection of resistance other than those exerted by the vector control program.

Conclusion: The results of this study have confirmed that An.gambiae have maintained and developed the resistance to pyrethroids, but are still susceptible to bendiocarb. Our data clearly shows that selection of resistant individuals was caused by other insecticides than those used by the IRS and LLINs.
\end{abstract}

Keywords: IRS, LLIN, Bendiocarb, Deltamethrin, Resistance, Kdr, Ace- $1^{R}$, Anopheles gambiae, Benin

\footnotetext{
* Correspondence: pagergil@yahoo.fr

${ }^{1}$ Faculté des Sciences et Techniques de I'Université d'Abomey Calavi, Calavi, Bénin

Full list of author information is available at the end of the article
} 


\section{Background}

Anopheles gambiae Giles (Diptera: Culicidae) is the major malaria vector in West Africa. In Benin it mainly transmits Plasmodium falciparum which is responsible for malaria [1]. An.gambiae exists in two distinct molecular forms, referred to as ' $M$ ' and ' $S$ ' based on the variation observed in molecular markers [2]. In subSaharan Africa, insecticide treated nets (ITNs) and indoor residual insecticide spraying (IRS) are the cornerstones of malaria vector control [3]. These vector control methods aim to reduce morbidity and mortality caused by malaria. ITNs and IRS have each been shown to be highly effective methods of malaria vector control in their own right. A recent review of the evidence of cost and consequences of large-scale vector control for malaria concluded that both ITNs and IRS are highly cost effective vector control strategies [4]. ITNs have been the mainstay of vector control in many countries in which the disease is endemic and where infrastructure limits or precludes the implementation of IRS [5]. Unfortunately the resistance of An.gambiae to insecticides used for malaria vector control has occurred. This resistance has been associated with all insecticidal compounds used for insect vectors of human disease, including African malaria vectors [6]. The ongoing spread of insecticide-resistant genes, such as the well-characterized $k d r$ mutations $[7,8]$ in populations of the major African malaria vectors, An. gambiae and its sibling species An. arabiensis [9-12], can seriously jeopardize the efficacy of vector control programs [13]. It has been shown that in West and West-Central Africa, the L1014F allele was frequent in the S molecular form of An. gambiae $[9,14,15]$, whereas only few $M$ form populations from the gulf of Guinea presented kdr-w alleles at low frequencies $[14,15]$, except in a few urban and peri-urban coastal areas where it reached high frequencies $[16,17]$. Several recent studies conducted in Benin [18-21] have also indicated that An.gambiae is highly resistant to pyrethroids and DDT, but not to bendiocarb. It is in this context that the National Malaria Control Program (NMCP) has undertaken a full coverage of the IRS in no-flood zones in the Oueme region coupled with the distribution of mosquito treated nets in flood zones. In the situation of vector resistance to pyrethroids, the ability to use other families of insecticides is one of the alternatives available for the malaria vector control. Thus, bendiocarb WP, which gave good results in experimental huts [20], was chosen by the NMCP for the IRS at the community level. Following the first spraying campaign implemented (July/August 2008), three other cycles (March/April 2009, March/April 2010, July/August 2010) of treatment were conducted in the Oueme region. Despite the residual activity of bendiocarb which was 4 months on cement surfaces [20], the number of rounds in 2008 and 2009 was dependent on financial resources available. IRS was not implemented in the flood zone because of the presence of water bodies, which could be at risk of contamination by insecticides. Therefore, 48,819 LLINs (Long-Lasting Insecticidal Nets, Permanet 2.0) were distributed to 47,524 households, with particular attention to children under-five and pregnant women, in October 2008 and May 2009. A quantity of $35,120 \mathrm{~kg}$ of deltamethrin $100 \%$ (719.4 mg per net) was contained in 48,819 LLINs distributed in the flood zone. For house spraying, a total of $128,132 \mathrm{~kg}$ of bendiocarb $80 \%$ was sprayed onto the walls of 166,910 human dwellings to protect a population of 512,491 in a no-flood zone.

Under these conditions, it is possible that the level of initial resistance has changed. Elsewhere in East Africa, no selection effect from the long-term use of ITNs on phenotypic resistance was noticed [22,23], whereas other studies reported a rapid increase of $k d r$ mutation after four years of ITNs community use in Kenya [24] and in Equatorial Guinea [17] following a large-scale insecticide residual spraying (IRS) program. There was a similar case in West Africa, where an increasing Leu-Phe knockdown resistance mutation in Anopheles gambiae from Niger following a nationwide long-lasting insecticide-treated nets implementation at the end of 2005 [25] was reported. Other studies have shown the effect of insecticide treated nets (ITNs) with pyrethroids on An. gambiae populations and the possible selection of $k d r$ alleles either in laboratory experiments [26] or experimental huts trials [27]. In Benin, the susceptibility levels of populations of An. gambiae to carbamates and organophosphates, the association of the reported high $k d r$ frequency with the resistance phenotype, and the occurrence of other possible mechanisms of resistance are poorly understood. The present study aimed to report the first case of the impact of the three years of large scale of IRS and LLINs interventions on phenotypic resistance, $k d r$ and $a c e-1^{R}$ alleles in natural populations of An. gambiae s.l. from southeast Benin. The results provide crucial information about potential effects of wide-scale IRS and LLIN coverage on $k d r$ and ace- $1^{R}$ mutation selection and possible effects on phenotypic resistance to deltamethrin and bendiocarb in order to improve the malaria vector control programs.

\section{Methods}

\section{Study area}

The study area is located in the Southeast of Benin (West Africa) and includes four districts of the Oueme region: Adjohoun, Dangbo, Misserete and Seme (Figure 1). The four districts covered $977 \mathrm{~km}^{2}$ and an estimated 


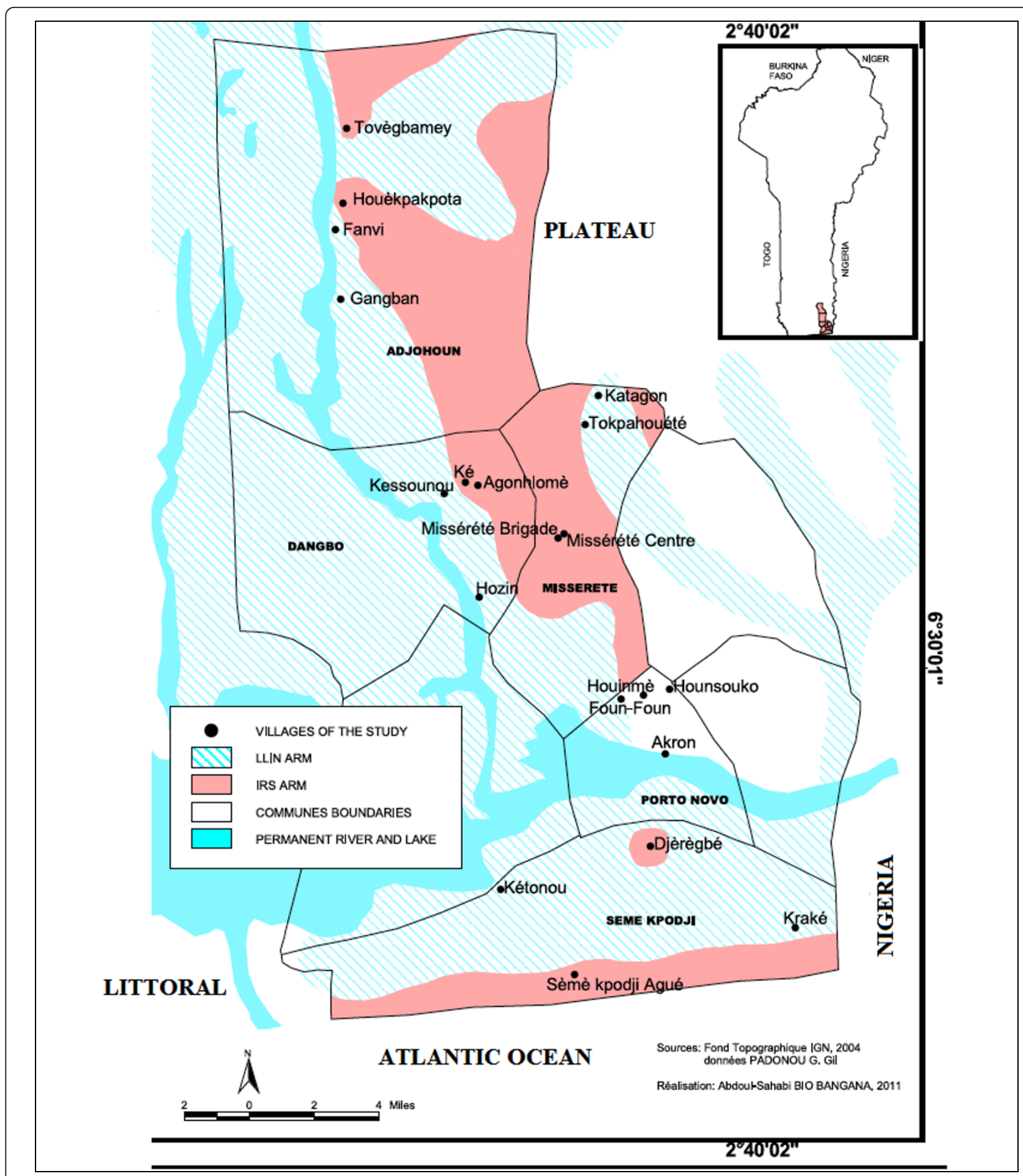

Figure 1 Map of the study area.

64,799 households. Oueme region has a sub-equatorial type climate with a monthly average temperature ranging from $20^{\circ} \mathrm{C}$ to $34^{\circ} \mathrm{C}$ and an annual average rainfall between 1,300 and $1,700 \mathrm{~mm}$. Malaria transmission is stable in the Oueme region, which is irrigated by the river Oueme, Lake Nokoue and the lagoon of PortoNovo. These streams determine two ecological zones in the Oueme region: a plateau zone and a flood zone. In the present study, the plateau zone is referred to as the" IRS area", and the flood zone is called "LLIN area". An 
estimated distance between 5 and $7 \mathrm{~km}$ separated the plateau and the flood areas. This distance was sufficient enough to prevent migration of mosquitoes from one area to another. The density of the human population was as high in IRS areas as in the flood zone, so that mosquitoes do not need to fly far away for blood feeding [28]. According to RTI, the coverage rate of IRS was more than $90 \%$ for each of the first three rounds.

In a context where universal access to LLINs was promoted, it was not easy to find a good control area. However, Porto-Novo, an area that presents the same ecological and geographical characteristics as the four districts mentioned above was chosen as control.

There is no IRS and free distribution of LLINs in Porto-Novo. Nevertheless some people who had bed nets, especially children and pregnant women, used them, but the proportion of consistent users was low. Before IRS implementation and the free distribution of LLINs, a baseline study of phenotype resistance with $k d r$ and $a c e-1^{R}$ frequencies in An.gambiae populations was carried out in the study area. The baseline data is shown here for a comparison before and after interventions.

\section{Insecticides used for IRS and ITNs}

Bendiocarb 80\%WP (Wettable powder) was selected for spraying onto the walls in IRS area. The application dose was $0.4 \mathrm{~g} / \mathrm{m}^{2}$ of bendiocarb on walls of houses. The four applications were implemented by volunteers selected from the local community and trained by the Research Triangle Institute (RTI) team, the implementing partner of the U.S. Agency for International Development. Nets distributed in the flood zones (LLIN area) were PermaNet 2.0. PermaNet 2.0 is a WHO recommended polyester LLIN coated with the pyrethroid deltamethrin to a target dose of $55 \mathrm{mg} / \mathrm{m}^{2}( \pm 25 \%)$.

\section{Study design and mosquito collections}

The mosquito sampling was conducted before the implementation of the IRS and LLIN free distribution, to provide baseline data on $k d r$ and $a c e-1^{R}$ mutation frequency, whereas other collections were carried out during two years after interventions (in 2009, 13 months after the first round of IRS and 11 months after the first LLIN distribution; in 2010, 24 months after the first round of IRS and 23 months after the first LLIN distribution). To carry out this sampling, four villages, including two in the IRS area and two in the LLIN area were randomly selected in each district and two human dwellings were chosen per village for mosquito collection using human landing catches (HLC). Similarly, four villages were chosen in the control area that had received no intervention (two as IRS control area and two as LLIN control area). Adult mosquitoes were collected twice a month with one collector located inside and another outside in each village. Mosquito collections were carried out twice a month, during three months in the wet season (September to November) in 2007, 2009 and 2010. The same human dwellings were used for HLC during the study and their characteristics were the same throughout the study. Female An. gambiae species were morphologically identified using morphological keys [29] and put into microtubes with dessicant, and then stored between -20 and $-28^{\circ} \mathrm{C}$ in the laboratory before processing. Additionally in the same period of wet season in 2007, 2009 and 2010, some larval samples were simultaneously collected. Ten of the previous villages including two in each district of Dangbo and Misserete IRS area, two in each district of Adjohoun and Seme LLIN area, two in the control area were taken into account. In each village selected $A n$. gambiae larvae and pupae were collected using the dipping method on several breeding sites (brick pits, pools, marshes, streams, ditches, pits dug for plastering traditional huts, puddles of water, water pockets caused by the passage of cattle and gutters) near human dwellings where the conditions of blood meals are available for Anopheles. The larvae and pupae were kept in separated labeled bottles related to each locality. Some of the larval samples were reared up to adult emergence at the CREC (Centre de Recherche Entomologique de Cotonou, Benin) insectary under standard conditions $(25 \pm$ $2^{\circ} \mathrm{C} ; 80 \% \pm 4 \%$ : Relative Humidity), for further bioassay tests. A strain of An. gambiae (Kisumu) was used as reference strain to compare the susceptibility levels of the field populations.

\section{Species identification}

All mosquitoes collected by HLC and all live and dead specimens of An. gambiae from the bioassay test were subjected to the An. gambiae species specific PCR assays for species identification [30]. Aliquots of DNA extracted from PCR positive specimens of An. gambiae s.s. were subjected to PCR assays for identification of the molecular ' $\mathrm{M}$ ' and ' $\mathrm{S}$ ' forms [31].

\section{PCR detection of the $k d r$ and ace. $1^{R}$ mutations}

Polymerase chain reaction diagnostic test for detection of $k d r$ "Leu-phe" mutation was carried out on An. gambiae mosquitoes as described by Martinez-Torres et al. [7]. The PCR-RFLP diagnostic test was used to detect the presence of G119S mutation (ace. $1^{R}$ gene) as described by Weill et al. [32].

\section{Insecticide susceptibility test}

The insecticide susceptibility test was carried out before and after the interventions in two districts (Dangbo and Misserete) of the IRS area and in two others districts 
(Adjohoun and Seme) for the LLIN area. Female mosquitoes aged 2-5 days old were exposed to diagnostic doses of various insecticides for susceptibility tests using insecticide-impregnated papers, as described by the standard WHO testing protocol [26]. The following insecticides were tested: deltamethrin $(0.05 \%)$, permethrin $(0.75 \%)$, DDT (4\%) and bendiocarb (0.1\%). The emphasis was also put on deltamethrin, because of a distribution of PermaNets by the NMCP in the swampy area. The use of DDT is justified by the detection of cross-resistance between pyrethroids and organo-chlorine in Anopheles populations [9]. Bendiocarb (carbamate) was the insecticide used in the IRS area situated far from flood zone. For each district, five test tubes were used: one untreated paper as a control and four treated papers to expose mosquitoes. Control tubes contained filter papers impregnated with silicon oil (insecticide carrier) only, whereas treated papers were impregnated with diagnostic doses of insecticide plus carrier. An average of twenty-five mosquitoes were introduced into each tube. Females of $A n$. gambiae used in this study were exposed for one hour to insecticidetreated papers and monitored at different time intervals $(10,15,20,30,45,60$ minutes $)$ to record the "knockdown" times. After 1 hour exposure, mosquitoes were transferred into holding tubes and provided with cotton wool wet with a $10 \%$ honey solution. Mortalities were recorded after 24 hours and the susceptibility status of the population was graded according to the WHO recommended protocol [33]. Dead and surviving mosquitoes from this bioassay were kept separately in Carnoy solution at $-20^{\circ} \mathrm{C}$ for further molecular characterization.

\section{Statistical analysis}

Using R software version 2.11.1 [34], a univariate logistic regression, was performed with $k d r$ frequency as the dependent variable and the year as a covariate with ANOVA test to determine the association of $k d r$ frequency (dependent variable) on the one hand with the localities and also with the years 2007, 2009 and 2010 (covariates) on the other hand. This regression has also been used to appreciate the $k d r$ frequency in the intervention areas compared to the control areas. This was the same to test the association between mortality rates (dependent variable) to insecticides and localities (covariates). The ANOVA test was used to assess this association. The Wald test has been used to compare $k d r$ frequency and mortality rates in the intervention areas with the control areas. To compare the ace-1 frequency between the intervention areas and the control areas we used the Fisher exact test (Genepop software) [35] as the gene is rarely observed in mosquitoes tested. Similarly the comparison of the $k d r$ and ace-1 frequencies from one year to another in each locality was performed using Fisher's exact test and chi-square test. A Kendall correlation test was used to study the correlation between mortality rates and survivors to deltamethrin with $k d r$ frequency. The significance level was set at $5 \%$.

\section{Ethical approval}

This study received the approval of the Ministry of Health and the National Ethics Committee. The voluntary mosquito collectors gave their consent before participating in the study. They were also subjected to regular medical check-ups with preventive treatments of malaria. They were all vaccinated against yellow fever.

\section{Results}

Species and molecular forms of Anopheles gambiae

Species and molecular forms of An. gambiae s.l. collected from 2007-10 by HLC are shown in Table 1. During this study, An gambiae s.s was the only member identified in the $A n$. gambiae complex. The analysis showed that all An. gambiae s.s collected were molecular $\mathrm{M}$ form. No $\mathrm{S}$ form was found during the study period.

\section{$\mathrm{Kdr}$ and ace. $1^{R}$ frequencies in An. gambiae s.l. collected by HLC}

The $k d r$ mutation was the main mechanism of pyrethroid resistance identified in all localities from 2007 to 2010. Univariate logistic regression, performed with $k d r$ frequency as the dependent variable and year as a covariate with ANOVA test, showed for the whole IRS area, that the $k d r$ frequency was associated with the time $(\mathrm{p}<0.05)$ and decreased significantly in 2009 compared to 2007 (OR $=0.756<1$; p < 0.05). However, it has increased significantly in 2010 compared to 2009 $(\mathrm{OR}=8.120>1 ; \mathrm{p}<0.05)$. Conversely, in the LLIN area, the increase in $k d r$ frequency was not significant in 2009 compared to 2007 (OR $=1.295>1$; p > 0.05) but it was significant in 2010 compared to 2009 (OR = $5.107>1 ; \mathrm{p}<0.05)$. Indeed, the $k d r$ gene frequencies observed were similar in 2007 and 2009 in Dangbo, Misserete, Adjohoun and Seme LLIN area but had significantly increased in 2010 (Table 1). In the control area the level of $k d r$ gene frequencies was very high and stable from 2007 to 2010 ( $\mathrm{p}>0.05)$. The ace- $1^{R}$ mutation was $0 \%$ from 2007 to 2009 in all localities. But in 2010 , heterozygous (RS) individuals of $a c e-1^{R}$ mutation were detected in all localities 24 months after the first round of IRS, except in Adjohoun, Seme LLIN and control LLIN. This variation (0-13\%) was significant in Seme IRS in contrast to insignificant increase $(p>0.05)$ noticed in the localities of Control IRS, Dangbo IRS, Misserete IRS and Dangbo LLIN. A univariate logistic regression with ANOVA test showed that the increase 
Table 1 Species identification, molecular forms, $k d r$ and $a c e-1^{R}$ frequencies in An.gambiae s.l. collected by HLC

\begin{tabular}{|c|c|c|c|c|c|c|c|c|c|c|c|c|}
\hline \multirow[b]{2}{*}{ Localities } & \multirow[b]{2}{*}{ Years } & \multirow[b]{2}{*}{$\mathrm{N}$} & \multirow{2}{*}{$\begin{array}{c}\text { Species } \\
\mathrm{Ag} \\
\end{array}$} & \multirow{2}{*}{$\begin{array}{c}\text { Molecular forms } \\
M \text { form }\end{array}$} & \multicolumn{4}{|c|}{$\begin{array}{l}\text { kdr mutation } \\
\text { (M form) }\end{array}$} & \multicolumn{4}{|c|}{$\begin{array}{l}\text { ace. } 1^{R} \text { mutation } \\
\text { (M form) }\end{array}$} \\
\hline & & & & & RR & RS & SS & $k d r \mathrm{f}$ & RR & $\mathrm{RS}$ & SS & ace. $1^{R} \mathrm{f}$ \\
\hline \multirow[t]{3}{*}{ Control IRS } & 2007 & 22 & 22 & 22 & 20 & 2 & 0 & $0.95^{\mathrm{a}}$ & 0 & 0 & 22 & $0^{a}$ \\
\hline & 2009 & 21 & 21 & 21 & 18 & 3 & 0 & $0.92^{\mathrm{a}}$ & 0 & 0 & 21 & $0^{\mathrm{a}}$ \\
\hline & 2010 & 39 & 39 & 39 & 35 & 04 & 0 & $0.95^{\mathrm{a}}$ & 0 & 5 & 34 & $0.06^{\mathrm{a}}$ \\
\hline \multirow[t]{3}{*}{ Adjohoun IRS } & 2007 & 74 & 74 & 74 & 28 & 34 & 12 & $0.61^{a}$ & 0 & 0 & 74 & $0^{a}$ \\
\hline & 2009 & 122 & 122 & 122 & 48 & 56 & 18 & $0.62^{a}$ & 0 & 0 & 122 & $0^{a}$ \\
\hline & 2010 & 24 & 24 & 24 & 21 & 3 & 0 & $0.94^{b}$ & 0 & 0 & 24 & $0^{a}$ \\
\hline \multirow[t]{3}{*}{ Dangbo IRS } & 2007 & 150 & 150 & 150 & 85 & 59 & 6 & $0.76^{a}$ & 0 & 0 & 150 & $0^{\mathrm{a}}$ \\
\hline & 2009 & 263 & 263 & 263 & 133 & 115 & 15 & $0.72^{a}$ & 0 & 0 & 263 & $0^{a}$ \\
\hline & 2010 & 68 & 68 & 68 & 65 & 3 & 0 & $0.98^{b}$ & 0 & 4 & 64 & $0.03^{b}$ \\
\hline \multirow[t]{3}{*}{ Misserete IRS } & 2007 & 89 & 89 & 89 & 58 & 31 & 0 & $0.83^{a}$ & 0 & 0 & 89 & $0^{\mathrm{a}}$ \\
\hline & 2009 & 129 & 129 & 129 & 86 & 35 & 8 & $0.80^{\mathrm{a}}$ & 0 & 0 & 129 & $0^{\mathrm{a}}$ \\
\hline & 2010 & 46 & 46 & 46 & 43 & 3 & 0 & $0.97^{b}$ & 0 & 2 & 44 & $0.02^{b}$ \\
\hline \multirow[t]{3}{*}{ Sèmè IRS } & 2007 & 122 & 122 & 122 & 109 & 1 & 12 & $0.90^{a}$ & 0 & 0 & 122 & $0^{a}$ \\
\hline & 2009 & 190 & 190 & 190 & 143 & 17 & 30 & $0.80^{\mathrm{b}}$ & 0 & 0 & 190 & $0^{a}$ \\
\hline & 2010 & 22 & 22 & 22 & 19 & 3 & 0 & $0.93^{\mathrm{a}}$ & 0 & 6 & 16 & $0.13^{b}$ \\
\hline \multirow[t]{3}{*}{ Control LLIN } & 2007 & 150 & 150 & 150 & 110 & 40 & 0 & $0.87^{a}$ & 0 & 0 & 150 & $0^{a}$ \\
\hline & 2009 & 101 & 101 & 101 & 90 & 11 & 0 & $0.95^{\mathrm{b}}$ & 0 & 0 & 101 & $0^{a}$ \\
\hline & 2010 & 43 & 43 & 43 & 38 & 5 & 0 & $0.94^{b}$ & 0 & 0 & 43 & $0^{\mathrm{a}}$ \\
\hline \multirow[t]{3}{*}{ Adjohoun LLIN } & 2007 & 52 & 52 & 52 & 14 & 30 & 8 & $0.56^{a}$ & 0 & 0 & 52 & $0^{a}$ \\
\hline & 2009 & 24 & 24 & 24 & 8 & 16 & 0 & $0.67^{a}$ & 0 & 0 & 24 & $0^{a}$ \\
\hline & 2010 & 17 & 17 & 17 & 15 & 2 & 0 & $0.94^{b}$ & 0 & 0 & 17 & $0^{a}$ \\
\hline \multirow[t]{3}{*}{ Dangbo LLIN } & 2007 & 124 & 124 & 124 & 66 & 54 & 4 & $0.75^{a}$ & 0 & 0 & 124 & $0^{a}$ \\
\hline & 2009 & 96 & 96 & 96 & 50 & 40 & 6 & $0.73^{a}$ & 0 & 0 & 96 & $0^{\mathrm{a}}$ \\
\hline & 2010 & 58 & 58 & 58 & 55 & 3 & 0 & $0.97^{b}$ & 0 & 3 & 55 & $0.02^{\mathrm{a}}$ \\
\hline \multirow[t]{3}{*}{ Sèmè LLIN } & 2007 & 72 & 72 & 72 & 60 & 0 & 12 & $0.83^{a}$ & 0 & 0 & 72 & $0^{a}$ \\
\hline & 2009 & 44 & 44 & 44 & 31 & 12 & 1 & $0.84^{a}$ & 0 & 0 & 44 & $0^{a}$ \\
\hline & 2010 & 7 & 7 & 7 & 7 & 0 & 0 & $1^{a}$ & 0 & 0 & 7 & $0^{a}$ \\
\hline
\end{tabular}

Ag: An. gambiae; $k d r$ f: $k d r$ frequency; ace. $1^{R}$ f: ace. $1^{R}$ frequency. Numbers in the same column sharing the same superscript do not differ significantly ( $\left.p>0,05\right)$

of $k d r$ frequencies is associated with the intervention areas and similarly with the control area $(\mathrm{p}<0.05)$. As the ace- $1^{R}$ allele was rarely observed in mosquitoes tested, the Fisher exact test, revealed that the $a c e-1^{R}$ frequency was similar in the intervention communities compared to the control area $(p>0.05)$.

\section{Insecticide susceptibility}

The susceptibility of adult mosquitoes (reared from larval collection) to permethrin $(0.75 \%)$, deltamethrin (0.05\%), DDT (4\%) and bendiocarb (0.1\%) from 2007-10 is presented in Figure 2. The resistance status of the mosquitoes was based on the decrease in the mortality rates according to WHO criteria. From 2007-10, the susceptible strain Kisumu of An. gambiae displayed mortality rates above $98 \%$ for the 4 insecticides tested (Figure 2). The $24 \mathrm{~h}$ post-exposure mortality rate of $A n$. gambiae s.l from all localities showed resistance to
DDT, permethrin and deltamethrin. In contrast, these mosquitoes were highly susceptible to bendiocarb with a mortality rate more than $99 \%$ (Figure 2). Univariate logistic regression, performed with mortality rate as the dependent variable and localities as a covariate with ANOVA test, showed that the phenotypic resistance to DDT and pyrethroid was associated with the localities $(\mathrm{p}<0.05)$. Indeed, logistic regression performed, showed a decrease of mosquito

susceptibility for permethrin $(\mathrm{OR}=0.70[0.51-0.95])$, $\mathrm{p}<0.05)$, deltamethrin $(\mathrm{OR}=0.27[0.15-0.51]), \mathrm{p}<$ $0.05)$ and DDT $(\mathrm{OR}=0.16[0.11-0.24]), \mathrm{p}<0.05)$ in Seme LLIN and for DDT (OR = 0.54 [0.39 - 0.75]), $\mathrm{p}<$ 0.05) in Adjohoun LLIN. This finding was similar to Misserete IRS for permethrin $(\mathrm{OR}=0.53$ [0.39 - 0.72]), $\mathrm{p}<0.05)$, deltamethrin $(\mathrm{OR}=0.27[0.15-0.51]), \mathrm{p}<$ $0.05)$ and DDT $(\mathrm{OR}=0.47[0.34-0.66]), \mathrm{p}<0.05)$, to Dangbo IRS for permethrin $(\mathrm{OR}=0.63[0.47-0.84]), \mathrm{p}$ 


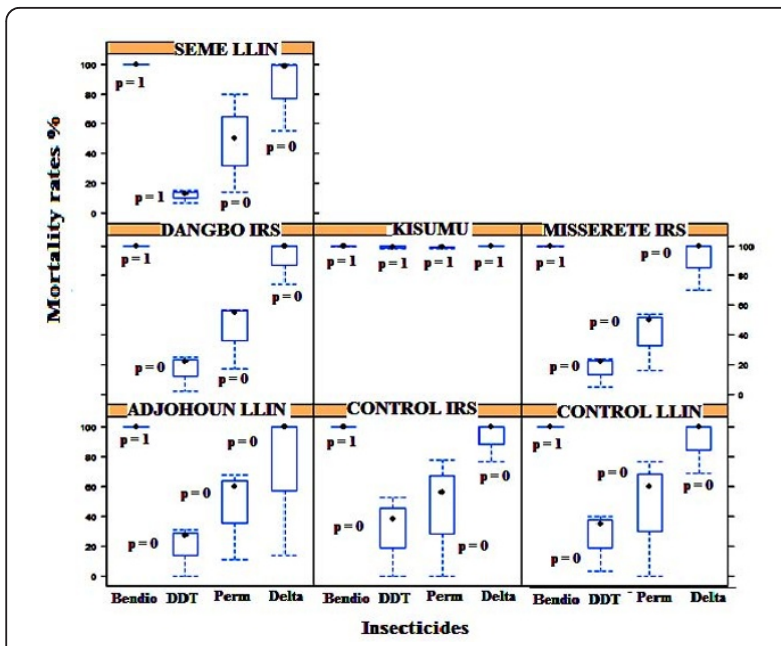

Figure 2 Variation of mortality rates per insecticide from 2007 to 2010 in each locality.

$<0.05)$ and DDT (OR $=0.51[0.37-0.71]), \mathrm{p}<0.05)$ compared to the control IRS area. Concerning the mortality rate of An. gambiae to deltamethrin ( $\mathrm{OR}=0.51$ $[0.26-1])$ and permethrin $(\mathrm{OR}=0.82[0.6-1.12])$ in Adjohoun they were similar $(\mathrm{p}>0.05)$ to the control LLIN area. The susceptibility to bendiocarb did not change in the LLINs and IRS areas compared to the control area $(\mathrm{p}>0.05)$.

\section{$K d r$ and $a c e .1^{R}$ frequencies in survivors and dead (susceptible) An. gambiae s.l. to insecticides}

Ace- $1^{R}$ mutation was not detected in 2 survivors and all 200 randomly drawn dead mosquitoes from the reared strain of An. gambiae s.l specimens which were scored for the allele. The $k d r$ genotyping performed on dead and surviving mosquitoes to deltamethrin showed that $100 \%$ of them were An gambiae s.s $\mathrm{M}$ form. During the study period, $k d r$ frequencies in alive and dead mosquito specimens from Dangbo IRS, Misserete IRS, Seme LLIN and Control area have been relatively high and has not varied significantly $(\mathrm{p}>0.05$ ) (Tables 2,3$) . K d r$ frequencies were respectively in the range of 0.78-0.91 for alive and 0.72-0.90 for dead mosquitoes (Tables 2, 3). Whereas in the Adjohoun LLIN area, it was stable at $0.60-0.64 \%$ in $2007-09$ and varied to 0.83 in 2010 for live specimens (Table 2). This is the same with the $k d r$ allelic frequencies in dead mosquitoes, specimens which were in the range of $0.67-0.66 \%$ in 2007-09 and varied to 0.77 in 2010 (Table 3). The correlation coefficients between the $k d r$ frequency in survivors and mortality rates to deltamethrin were respectively $-0.54(\mathrm{P}>0.05)$,

Table 2 Kdr frequency in surviving An.gambiae s.l. population $24 \mathrm{~h}$ post-exposure to insecticides

\begin{tabular}{|c|c|c|c|c|c|c|c|c|}
\hline \multirow[t]{2}{*}{ Locality } & \multirow[t]{2}{*}{ Years } & \multirow{2}{*}{$\begin{array}{l}\text { Number of survivors } \\
\text { tested }\end{array}$} & \multirow{2}{*}{$\begin{array}{l}\text { Species } \\
\text { Ag }\end{array}$} & \multirow{2}{*}{$\begin{array}{c}\text { Molecular } \\
\text { forms } \\
\text { M }\end{array}$} & \multicolumn{4}{|c|}{$k d r$ mutation } \\
\hline & & & & & RR & RS & SS & $\begin{array}{c}k d r \text { frequency } \\
(\%)\end{array}$ \\
\hline \multirow{3}{*}{$\begin{array}{c}\text { Control area } \\
\text { (Plateau zone) }\end{array}$} & 2007 & 27 & 27 & 27 & 21 & 6 & 0 & $0.89^{a}$ \\
\hline & 2009 & 30 & 30 & 30 & 24 & 6 & 0 & $0.90^{\mathrm{a}}$ \\
\hline & 2010 & 25 & 25 & 25 & 22 & 3 & 0 & $0.86^{\mathrm{a}}$ \\
\hline \multirow[t]{3}{*}{ Control area (Flood zone) } & 2007 & 25 & 25 & 25 & 21 & 4 & 0 & $0.92^{a}$ \\
\hline & 2009 & 28 & 28 & 28 & 23 & 5 & 0 & $0.91^{\mathrm{a}}$ \\
\hline & 2010 & 25 & 25 & 25 & 22 & 3 & 0 & $0.82^{a}$ \\
\hline \multirow[t]{3}{*}{ Adjohoun (LLIN area) } & 2007 & 50 & 50 & 50 & 22 & 20 & 8 & $0,64^{a}$ \\
\hline & 2009 & 30 & 30 & 30 & 11 & 14 & 5 & $0,60^{a}$ \\
\hline & 2010 & 24 & 24 & 24 & 16 & 8 & 0 & $0.83^{\mathrm{b}}$ \\
\hline \multirow[t]{3}{*}{ Dangbo (IRS area) } & 2007 & 58 & 58 & 58 & 37 & 17 & 4 & $0,78^{\mathrm{a}}$ \\
\hline & 2009 & 60 & 60 & 60 & 38 & 22 & 0 & $0.82^{\mathrm{a}}$ \\
\hline & 2010 & 25 & 25 & 25 & 19 & 6 & 0 & $0.88^{\mathrm{a}}$ \\
\hline \multirow[t]{3}{*}{ Misserete (IRS area) } & 2007 & 56 & 56 & 56 & 40 & 16 & 0 & $0.86^{a}$ \\
\hline & 2009 & 30 & 30 & 30 & 23 & 6 & 1 & $0.87^{a}$ \\
\hline & 2010 & 22 & 22 & 22 & 18 & 4 & 0 & $0.91^{a}$ \\
\hline \multirow[t]{3}{*}{ Seme (LLIN area) } & 2007 & 54 & 54 & 54 & 49 & 1 & 4 & $0,92^{\mathrm{a}}$ \\
\hline & 2009 & 21 & 21 & 21 & 19 & 2 & 0 & $0,95^{\mathrm{a}}$ \\
\hline & 2010 & 25 & 25 & 25 & 20 & 5 & 0 & $0,90^{\mathrm{a}}$ \\
\hline
\end{tabular}

Ag: An. gambiae; Numbers in the same column sharing the same superscript do not differ significantly $(p>0,05)$ 
Table $3 \mathrm{Kdr}$ frequency in dead An.gambiae s.l. population $24 \mathrm{~h}$ post-exposure to insecticides

\begin{tabular}{|c|c|c|c|c|c|c|c|c|}
\hline \multirow[t]{2}{*}{ Locality } & \multirow[t]{2}{*}{ Years } & \multirow{2}{*}{$\begin{array}{c}\text { Number of } \\
\text { dead } \\
\text { tested }\end{array}$} & \multirow[t]{2}{*}{ Species Ag } & \multirow{2}{*}{$\begin{array}{c}\text { Molecular } \\
\text { forms } \\
\text { M }\end{array}$} & \multicolumn{4}{|c|}{$k d r$ mutation } \\
\hline & & & & & $\mathrm{RR}$ & RS & SS & $\begin{array}{c}k d r \text { frequency } \\
(\%)\end{array}$ \\
\hline \multirow[t]{3}{*}{ Control area (Plateau zone) } & 2007 & 27 & 27 & 27 & 20 & 7 & 0 & $0.87^{\mathrm{a}}$ \\
\hline & 2009 & 30 & 30 & 30 & 22 & 8 & 0 & $0.87^{\mathrm{a}}$ \\
\hline & 2010 & 25 & 25 & 25 & 20 & 3 & 2 & $0.86^{\mathrm{a}}$ \\
\hline \multirow{3}{*}{$\begin{array}{l}\text { Control area } \\
\text { (Flood zone) }\end{array}$} & 2007 & 25 & 25 & 25 & 20 & 5 & 0 & $0.90^{\mathrm{a}}$ \\
\hline & 2009 & 28 & 28 & 28 & 20 & 8 & 0 & $0.86^{\mathrm{a}}$ \\
\hline & 2010 & 25 & 25 & 25 & 19 & 3 & 3 & $0.82^{a}$ \\
\hline \multirow{3}{*}{$\begin{array}{l}\text { Adjohoun } \\
\text { (LLIN area) }\end{array}$} & 2007 & 50 & 50 & 50 & 21 & 25 & 4 & $0.67^{\mathrm{a}}$ \\
\hline & 2009 & 30 & 30 & 30 & 15 & 10 & 5 & $0,66^{a}$ \\
\hline & 2010 & 24 & 24 & 24 & 14 & 9 & 1 & $0,77^{b}$ \\
\hline \multirow{3}{*}{$\begin{array}{l}\text { Dangbo } \\
\text { (IRS area) }\end{array}$} & 2007 & 58 & 58 & 58 & 33 & 19 & 6 & $0,73^{a}$ \\
\hline & 2009 & 60 & 60 & 60 & 34 & 22 & 4 & $0,75^{\mathrm{a}}$ \\
\hline & 2010 & 25 & 25 & 25 & 15 & 6 & 4 & $0.72^{\mathrm{a}}$ \\
\hline \multirow[t]{3}{*}{ Misserete (IRS area) } & 2007 & 56 & 56 & 56 & 39 & 17 & 0 & $0.85^{\mathrm{a}}$ \\
\hline & 2009 & 30 & 30 & 30 & 22 & 6 & 3 & $0.81^{a}$ \\
\hline & 2010 & 22 & 22 & 22 & 18 & 4 & 3 & $0.80^{\mathrm{a}}$ \\
\hline \multirow[t]{3}{*}{ Seme (LLIN area) } & 2007 & 54 & 54 & 54 & 45 & 5 & 4 & $0.88^{\mathrm{a}}$ \\
\hline & 2009 & 21 & 21 & 21 & 15 & 5 & 1 & $0,83^{a}$ \\
\hline & 2010 & 25 & 25 & 25 & 19 & 4 & 2 & $0,84^{a}$ \\
\hline
\end{tabular}

Ag: An. gambiae; Numbers in the same column sharing the same superscript do not differ significantly $(p>0,05)$

$-0.43(\mathrm{P}>0.05)$ and $0.84(\mathrm{P}<0.05)$ in 2007 year, 2009 and 2010.

\section{Discussion}

The results have shown that An. gambiae s.s. M form was the major malaria vector species biting in the Oueme region. This corroborates previous reports [21] of the anopheline distribution in southeast Benin, which explained the absence of the $S$ molecular form by the ecological characteristics of the Oueme region that did not support its selection. The findings have also shown that $k d r$ gene frequencies were stable from 2007 to 2009 in the LLIN area but had significantly increased in 2010. Despite the LLIN distribution, the cause of this stability of $k d r$ gene frequencies from 2007 to 2009 is unknown, because the same results were obtained in the control area that has not benefited from the distribution of LLINs. But, a similar trend reported by a study in Bioko between 1998 and 2001 showed no evidence of $k d r$ in the $A n$. gambiae s.s. population despite the use of pyrethroid-impregnated bednets [36]. It was on the basis of this study that the decision was made to implement IRS with a pyrethroid insecticide in Bioko [37]. However, in 2010, a significant increase of $k d r$ mutation frequency was observed in Dangbo, Misserete, Adjohoun and Seme LLIN around 23 months after the first LLIN distribution, and 16 months after the second. This increase was corroborated with the strong correlation (correlation coefficient $\left.\mathrm{R}^{2}=0.84 ; \mathrm{P}<0.05\right)$ between the $k d r$ frequency and the survival rate obtained among the $A n$. gambiae s.l. populations tested with deltamethrin. Indeed the main mechanism of resistance to pyrethroids is the mutation Leu 1014F $k d r$ allele in Benin. Recent studies have shown that this mutation is expanding in the South [21,38] and North Benin [38]. This high mutation could explain the resistance to deltamethrin in An. gambiae collected from HLC and breeding sites of all localities including the control area, in 2010, two years after the implementation of vector control. Similarly, the resistance to permethrin and DDT has been maintained and became higher. These findings corroborate previous studies that had reported resistance of $A n$. gambiae to DDT and permethrin in Benin [18,21,39] and in Ethiopia [40] to DDT, permethrin and deltamethrin. Although suspected, the selective pressure exerted by the promotion of mosquito nets by the Ministry of Health and the free distribution of LLINs in the Oueme region, causing the $k d r$ increase within $A n$. gambiae 
populations is doubtful. Because the findings showed a significant decrease in deltamethrin mortality rates from $85 \%$ to $46 \%$ in LLIN area and $32 \%$ to $22 \%$ in IRS area and control area. Other previous studies have shown that the selection of resistance to pyrethroids in the populations of malaria vectors was due to the extensive use of LLIN $[41,42]$. Hence, resistance selection in the An. gambiae population to deltamethrin seemed most likely to have been developed as a consequence of exposure of adult mosquitoes to this insecticide from LLINs distributed in LLIN areas. Moreover, the high domestic pyrethroid use $[18,21]$, the contamination of soil by using pesticides for crop protection [18] in the Oueme region, could justify the resistance to deltamethrin in control and IRS areas who had not benefited from the distribution of LLINs. This hypothesis was supported by previous studies in Mali that showed an increase in $k d r$ frequencies in the absence of any wide-scale control program [12]. This diversity of factors (LLINs, IRS, mosquito coils, aerosols, use of pesticides for crop protection) that select individual resistant An. gambiae could also explain the spatial variation of low susceptibility of mosquitoes to insecticides. $K d r$ resistance gene was not the only mechanism of resistance observed in the Oueme region. This could justify the highest $k d r$ frequency observed among the strain susceptible to deltamethrin. According to previous studies in Benin, high activity of esterases and oxidases was detected in populations of An. gambiae and Culex quinquefasciatus resistant to pyrethroids [26]. Hence, further investigations are required to determine the role of $k d r$ in conferring resistance and the presence of other resistance mechanisms involved in the different classes of insecticides [43]. Indeed, when exposed to several insecticides, An. gambiae develops a resistance to these chemicals through several mechanisms of adaptation. Therefore, major challenges to malaria control in Africa must include the monitoring of resistance of mosquitoes to insecticides, but should also involve the education of people on the appropriate use of insecticides.

After four rounds of bendiocarb IRS from 2008 to 2010, An. gambiae remained susceptible to bendiocarb. This finding is in agreement with a previous study conducted in Benin $[20,21,44]$ and in Bioko where the number of $A n$. gambiae s.s. exiting through window traps were significantly reduced and remained low with subsequent IRS rounds with a bendiocarb [4]. This susceptibility of An. gambiae to bendiocarb may be explained by the absence of individual homozygous RR in the Oueme region. In Culex pipiens populations the ace-1 mutation has been associated with a high fitness cost [45] and the same may be true in An. gambiae s.s. as the frequency of the ace-1 mutation in mosquito populations declines rapidly after a few generations in the absence of selection pressure from organophosphates or carbamates insecticides [46]. Similarly, Djogbenou et al. reported that the main cost of resistance found for $A n$. gambiae mosquitoes homozygous for the G119S mutation was that they were significantly more likely to die during pupation than their susceptible counterparts [47]. But after the fourth round of IRS in 2010 heterozygous (RS) individuals of ace-1 mutations were detected in a few localities, with a significant variation (0-13\%) of ace1 frequency in Seme IRS in contrast to insignificant increase $(p>0.05)$ noticed in the localities of Control IRS, Dangbo IRS, Misserete IRS and Dangbo LLIN. This occurrence of heterozygous individuals, in the intervention area in 2010 could be attributed to a high selection pressure, because two rounds of IRS had been carried out that year. However, the occurrence of heterozygous individuals even at sites far from the sprayed areas, suggests other factors than those exerted by the vector control program. The ace-1 mutation may have migrated from treated to untreated areas, explaining the parallel increase in those areas. Conversely, the greater frequency of ace-1 mutation in An. gambiae specimens in Seme IRS, despite the fact that they are interspersed by at least $5 \mathrm{~km}$ with untreated control area and LLIN area, may suggest a possible migration of ace-1 mutation to untreated areas. If migration is restricted, the selection pressure in the untreated areas may be caused by other than the one induced by IRS. Indeed, recent studies $[18,48]$ showed that this region has a different bioclimatic characteristic with high rainfall $(1,500 \mathrm{~mm}$ annually), where insecticides are extensively used for agriculture. This suggests that selection of resistant individuals has been caused by insecticides used for other purposes apart from those used by the IRS, although it is difficult to identify the specific activity with the present study.

\section{Conclusion}

The results of this study have confirmed that natural populations of An.gambiae in the Oueme region have maintained and developed their resistance to pyrethroids, but are still susceptible to bendiocarb. In Africa the pyrethroid resistance had highly increased in $A n$ gambiae populations. This increase coincided with the period where chemical vector control was deployed with unprecedented levels of coverage in Africa. In this context there was selection of resistant individuals in the treated areas (LLINs and IRS), however, in untreated or control areas, the selection of resistance recorded may have been caused by unknown factors other than LLINs and IRS. These findings have important implications for malaria vector control programs using IRS and LLIN. Firstly, assessment and monitoring of resistance to pyrethroids and bendiocarb in malaria vector control should 
be a priority to help correct the current malaria preventive activities and guide in the selection of insecticides to use in the future for malaria vector control in Benin. Secondly, strategies for resistance management $[49,50]$ should be implemented to delay the development or expansion of insecticide resistance by the rotation or the mixture of different classes of insecticides with different target sites. Thirdly, it is necessary to implement a dialogue and partnerships between the fields of health and agriculture in order to coordinate the appropriate use of insecticides with reciprocal benefits for both parties.

\author{
Acknowledgements \\ We are grateful to the PMI (President Malaria Initiative), which financially \\ supported this study through USAID and RTI. The authors would like to \\ thank Adango Arnaud, Houndeton Geraldo, Koudenoukpo Sebastien, \\ Azondekon Roseric for their technical assistance apopulations of Adjohoun, \\ Dangbo, Seme, and Misserete for their collaboration.
}

\section{Author details}

'Faculté des Sciences et Techniques de I'Université d'Abomey Calavi, Calavi, Bénin. ${ }^{2}$ Centre de Recherche Entomologique de Cotonou (CREC), Cotonou, Bénin.

\section{Authors' contributions}

GGP, MS, RO and MA designed the study. GGP, NA and OO carried out the experiments. GGP and FO analyzed the data. GGP and MS drafted the manuscript. MA, GG and MS critically revised the manuscript. All authors read and approved the final manuscript.

\section{Competing interests}

The authors declare that they have no competing interests.

Received: 12 February 2012 Accepted: 10 April 2012

Published: 10 April 2012

\section{References}

1. Akogbeto M, Chippaux JP, Coluzzi M: Le paludisme urbain côtier à Cotonou (Republique du Benin). Revue Epidemiologie et Sante Publique. Rev Epidemiol Sante Publique 1992, 40:233-239.

2. Favia G, Lanfrancotti A, Spanos L, Sideen-Kiamos I, Louis C: Molecular characterization of ribosomal DNA polymorphisms discriminating among chromosomal forms of Anopheles gambiae s.s. Insect Mol Biol 2001, 10(1):19-23.

3. Curtis CF, Myamba J, Wilkes TJ: Comparison of different insecticides and fabrics for antimosquito bednets and curtains. Med Vet Entomol 1996, 10:1-11

4. Kleinschmidt I, Schwabe C, Shiva M, Segura JL, Sima V, Mabunda SJA, Coleman M: Combining indoor residual spraying and insecticide-treated net interventions. AmJTrop Med Hyg 2009, 81(3):519-524.

5. Roll Back Malaria Partnership: Consensus Statement on Insecticide-Treated Netting and Indoor Residual Spraying Geneva, World Health Organization; 2004 [http://rbm.who.int/partnership/wg/wg_LLIN/docs/RBMWIN StatementVector.pdf]

6. Hemingway J, Ranson $\mathrm{H}$ : Insecticide resistance in insect vectors of human disease. Annu Rev Entomol 2000, 45:371-391.

7. Martinez-Torres D, Chandre F, Williamson MS, Darriet F, Bergé JB, Devonshire AL, Guillet P, Pasteur N, Pauron D: Molecular characterization of pyrethroid knockdown resistance $(\mathrm{kdr})$ in the major malaria vector Anopheles gambiae s.s. Insect Mol Biol 1998, 7:179-184.

8. Ranson $H$, Jensen $B$, Vulule JM, Wang $X$, Hemingway J, Collins FH: Identification of a point mutation in the voltage-gated sodium channe gene of Kenyan Anopheles gambiae associated with resistance to DDT and pyrethroids. Insect Mol Biol 2000, 9:491-497.
9. Chandre F, Darriet F, Manguin S, Brengues C, Carnevale P, Guillet P: Pyrethroid cross resistance spectrum among populations of Anopheles gambiae s.s. from Côte d'Ivoire. J Am Mosa Control Assoc 1999, 15:53-59.

10. Diabate A, Brengues C, Baldet T, Dabiré KR, Hougard JM, Akogbeto M, Kengne $P$, Simard F, Guillet $P$, Hemingway J, Chandre F: The spread of the Leu-Phe kdr mutation through Anopheles gambiae complex in Burkina Faso: genetic introgression and de novo phenomena. Trop Med Int Health 2004, 9:1267-1273.

11. Etang J, Fondjo E, Chandre F, Morlais I, Brengues C, Nwane P. Chouaibou M, Ndjemai H, Simard F: First report of knockdown mutations in the malaria vector Anopheles gambiae from Cameroon. AmJTrop Med Hyg 2006, 74(5):795-797.

12. Tripet F, Wright J, Cornel A, Fofana A, McAbee R, Meneses C, Reimer L, Slotman M, Thiemann T, Dolo G, Traoré S, Lanzaro G: Longitudinal survey of knockdown resistance to pyrethroid (kdr) in Mali, West Africa, and evidence of its emergence in the Bamako form of Anopheles gambiae s. s. AmJTrop Med Hyg 2007, 76:81-87.

13. Chouaibou M, Etang J, Brevault T, Nwane P. Hinzoumbe CK, Mimpfoundi R, Simard F: Dynamics of insecticide resistance in the malaria vector Anopheles gambiae s.l. from an area of extensive cotton cultivation in Northern Cameroon. Trop Med Int Health 2008, 13:476-486.

14. Kristan M, Fleischmann H, Della Torre A, Stich A, Curtis Curtis CF: Pyrethroid resistance/susceptibility and differential urban/rural distribution of Anopheles arabiensis and An. gambiae s.s. malaria vectors in Nigeria and Ghana. Med Vet Entomol 2003, 17:326-332.

15. Santolamazza F, Calzetta M, Etang J, Barrese E, Dia I, Caccone A, Donnelly MJ, Petrarca V, Simard F, Pinto J, Della Torre A: Distribution of knock-down resistance mutations in Anopheles gambiae molecular forms in west and west-central Africa. Malar J 2008, 7:74.

16. Tia E, Akogbeto M, Koffi A, Toure M, Adja AM, Moussa K, Yao T, Carnevale P, Chandre E: Pyrethroid and DDT resistance of Anopheles gambiae s.s. (Diptera: Culicidae) in five agricultural ecosystems from Côte-d'Ivoire. Bull Soc Pathol Exot 2006, 99:278-282.

17. Reimer $L$, Tripet F, Slotman M, Spielman A, Fondjo E, Lanzaro GC: An unusual distribution of the kdr gene among populations of Anopheles gambiae on the island of Bioko, Equatorial Guinea. Insect Mol Biol 2005, 14:683-688.

18. Akogbeto $\mathrm{M}$, Yakoubou S: Resistance of malaria vectors to pyrethroids used for impregnating mosquito nets in Benin, West Africa. Bull Soc Pathol Exot 1999, 92(2):123-130

19. Corbel V, N'Guessan R, Brengues C, Chandre F, Djogbenou L, Martin T, Akogbéto M, Hougard JM, Rowland M: Multiple insecticide resistance mechanisms in Anopheles gambiae and Culex quinquefasciatus from Benin, West Africa. Acta Trop 2007, 101:207-216.

20. Akogbeto MC, Padonou GG, Gbenou D, Irish S, Yadouleton A: Bendiocarb, a potential alternative against pyrethroid resistant Anopheles gambiae in Benin, West Africa. Malar J 2010, 9:204.

21. Padonou GG, Sezonlin M, Gbedjissi GL, Ayi I, Azondekon R, Djenontin A, Bio-Bangana S, Oussou O, Yadouleton A, Boakye D, Akogbeto M: Biology of Anopheles gambiae and insecticide resistance: Entomological study for a large scale of indoor residual spraying in South East Benin. $J$ Parasitol Vector Biol 2011, 3(4):59-68

22. Vulule JM, Beach RF, Atieli FK, Mount DL, Roberts JM, Mwangi RW: Longterm use of permethrin-impregnated nets does not increase Anopheles gambiae permethrin tolerance. Med Vet Entomol 1996, 10:71-79.

23. Kulkarni MA, Malima R, Mosha FW, Msangi S, Mrema E: Efficacy of pyrethroid-treated nets against malaria vectors and nuisance- biting mosquitoes in Tanzania in areas with long-term insecticide-treated net use. Trop Med Int Health 2007, 12:1061-1073.

24. Stump AD, Atieli FK, Vulule JM, Besansky NJ: Dynamics of the pyrethroid knockdown resistance allele in western Kenyan populations of Anopheles gambiae in response to insecticide- treated bed net trials. AmJTrop Med Hyg 2004, 70:591-596.

25. Czeher C, Labbo R, Arzika I, Duchemin JB: Evidence of increasing Leu-Phe knockdown resistance mutation in Anopheles gambiae from Niger following a nationwide long-lasting insecticide-treated nets implementation. Malar \& 2008, 7:189.

26. Corbel V, Chandre F, Brengues C, Akogbeto M, Lardeux F: Dosage-dependent effects of permethrin-treated nets on the behaviour of Anopheles gambiae and the selection of pyrethroid resistance. Malar J 2004, 3:22. 
27. Asidi AN, N'Guessan R, Koffi AA, Curtis CF, Hougard JM: Experimental hut evaluation of bednets treated with an organophosphate (chlorpyrifosmethyl) or a pyrethroid (lambdacyhalothrin) alone and in combination against insecticide-resistant Anopheles gambiae and Culex quinquefasciatus mosquitoes. Malar J 2005, 4:25.

28. Akogbeto M, Padonou GG, Bankole HS, Gazard DK, Gbedjissi GL: Dramatic decrease in malaria transmission after large-scale indoor residual spraying with Bendiocarb in Benin, an area of high resistance of Anopheles gambiae to Pyrethroids. AmJTrop Med Hyg 2011, 85(4):586-593.

29. Gillies MT, De Meillon B: The Anophelinae of Africa south of the Sahara Publication of the South African Institute for Medical Research, Johannesburg; 1968, 54.

30. Scott JA, Brogdon WG, Collins FH: Identification of single specimens of Anopheles gambiae complex by polymerase chain reaction. AmJTrop Med Hyg 1993, 49:520-529.

31. Favia G, Della Torre A, Bagayoko M, Lanfrancotti, Sagnon NF, Toure Y, Coluzzi M: Molecular identification of sympatric chromosomal forms of Anopheles gambiae and further evidence of their reproductive isolation. Insect Mol Biol 1997, 6:377-383.

32. Weill M, Malcolm C, Chandre F, Mogensen K, Berthomieu A, Marquine M, Raymond M: The unique mutation in Ace-1 giving high insecticide resistance is easily detectable in mosquito vectors. Insect Mol Biol 2004, 13:1-7.

33. World Health Organisation: Test procedures for insecticide resistance monitoring in malaria vectors, bio-efficacy and persistence of insecticides on treated surfaces. Document WHO/CDS/CPC/MAL/98.12 Geneva, Switzerland 1998 [http://whqlibdoc.who.int/hq/1998/ WHO_CDS_CPC_MAL_98.12.pdf].

34. R Development Core Team: $\mathrm{R}$ A language and environment for statistical computing. 2.11.1. ed. Vienna Austria 2010.

35. Raymond M, Rousset F: GENEPOP (version 1.2): population genetics software for exact tests and ecumenicism. J Heredity 1995, 86:248-249.

36. Berzosa PJ, Cano J, Roche J, Rubia JM, Garcia L, Moyano E, Guerra A Mateos JC, Petraca V, Do Rosaria V, Benito A: Malaria vectors in Bioko island (Equatorial Guinea): PCR determination of the members of Anopheles gambiae Giles complex (Diptera: Culicidae) and pyrethoid knockdown resistance ( $k d r)$ in An. gambiae sensu stricto. J Vector. Ecology 2002, 27:102-106.

37. Sharp BL, Ridl FC, Govender D, Kuklinski J, Kleinschmidt I: Malaria vector control by indoor residual insecticide spraying on the tropical island of Bioko. Equatorial Guinea Malar J 2007, 6:52.

38. Djègbè I, Boussari $O$, Sidick $A$, Martin $T$, Ranson $H$, Chandre $F$, Akogbéto $M$, Corbel V: Dynamics of insecticide resistance in malaria vectors in Benin: first evidence of the presence of L1014S kdr mutation in Anopheles gambiae from West Africa. Malar J 2011, 10:261.

39. N'Guessan R, Corbel V, Akogbéto M, Rowland M: Reduced efficacy of insecticide-treated nets and indoor residual spraying for malaria control in pyrethroid resistance area, Benin. Emerg Infect Dis 2007, 13:199-206.

40. Balkew M, Ibrahim M, Koekemoer LL, Brooke BD, Engers H, Aseffa A, GebreMichael T, Elhassen I: Insecticide resistance in Anopheles arabiensis (Diptera: Culicidae) from villages in central, northern and south west Ethiopia and detection of kdr mutation. Parasit Vectors 2010, 3(1):40.

41. Lines JD: Do agricultural insecticides select for insecticide resistance in mosquitoes, a look at the evidence. Parasitol Today 1988, 4:17-20.

42. Protopopoff N, Verhaeghen K, Van Bortel W, Roelants P, Marcotty T, Baza D, D'Alessandro U, Coosemans M: A high increase in kdr in Anopheles gambiae is associated with an intensive vector control intervention in Burundi highlands. Trop Med Int Health 2008, 13:1479-1487.

43. Yewhalaw D, Wassie F, Steurbaut W, Spanoghe P, Van Bortel W, Denis L, Tessema DA, Getachew Y, Coosemans M, Duchateau, Speybroeck N: Multiple insecticide resistance: an impediment to insecticide-based malaria vector control program. PLOS One 2011, 6(1):16066.

44. Djogbenou L, Pasteur N, Akogbeto M, Weill M, Chandre F: Insecticide resistance in the Anopheles gambiae complex in Benin: a nationwide survey. Med Vet Entomol 2009, 69:160-164

45. Raymond M, Berticat C, Weill M, Pasteur N, Chevillon C: Insecticide resistance in the mosquito Culex pipiens: what have we learned about adaptation? Genetica 2001, 112:287-296.

46. Labbé $P$, Berthomieu A, Berticat C, Alout $H$, Raymond M, Lenormand T, Weill $\mathrm{M}$ : Independent duplications of the acetylcholinesterase gene conferring insecticide resistance in the mosquito Culex pipiens. Mol Biol Evol 2007, 24(4):1056-1067.

47. Djogbenou L, Noel V, Agnew P: Costs of insensitive acetylcholinesterase insecticide resistance for the malaria vector Anopheles gambiae homozygous for the G119S mutation. Malar J 2010, 9:12.

48. Yadouleton WA, Padonou G, Asidi A, Moiroux N, Banganna S, Corbel V, N'guessan R, Gbenou D, Yacoubou I, Gazard Kinde D, Akogbeto CM: Insecticide resistance status in Anopheles gambiae in southern Benin. Malar J 2010, 9:83.

49. Ngufor C, N'Guessan R, Boko P, Odjo A, Vigninou E, Asidi A, Akogbeto M, Rowland M: Combining indoor residual spraying with chlorfenapyr and long-lasting insecticidal bed nets for improved control of pyrethroidresistant Anopheles gambiae: an experimental hut trial in Benin. Malar J 2011, 10:343.

50. Corbel V, Henry MC: Prevention and control of malaria and sleeping sickness in Africa: where are we and where are we going? Parasit Vectors 2011, 4:37.

doi:10.1186/1756-3305-5-72

Cite this article as: Padonou et al:: Impact of three years of large scale Indoor Residual Spraying (IRS) and Insecticide Treated Nets (ITNs) interventions on insecticide resistance in Anopheles gambiae s.l. in Benin. Parasites \& Vectors 2012 5:72.

\section{Submit your next manuscript to BioMed Central and take full advantage of:}

- Convenient online submission

- Thorough peer review

- No space constraints or color figure charges

- Immediate publication on acceptance

- Inclusion in PubMed, CAS, Scopus and Google Scholar

- Research which is freely available for redistribution

Submit your manuscript at www.biomedcentral.com/submit
Ciomed Central 